\title{
Socioeconomic or Political Variables? The Determinants of Voter Turnout in Czech Municipalities ${ }^{1}$
}

\author{
Michael Haman - Milan Školník \\ Department of Political Science, University of Hradec Králové
}

\begin{abstract}
Socioeconomic or Political Variables? The Determinants of Voter Turnout in Czech Municipalities. The article contributes to the debate on the relationship between voter turnout and socioeconomic and political variables at the local level in the Czech Republic. We investigated the 2018 Czech municipal elections. We constructed an original datase composed of 6,229 municipalities. Also, we created a second dataset consisting of 205 municipalities with extended jurisdiction and Prague, which included a composite Index of quality of life (including variables that are part of development indices such as health, economic indicators, education, and many others). From a methodological point of view, we used statistical methods such as ordinary least squares regression to analyze data. We find that a higher quality of life in a municipality is positively associated with a higher voter turnout. Furthermore, the running incumbent does not have an effect on voter turnout. We find that the presence of at least two candidate lists in smaller municipalities increases voter turnout by $10 \%$. Also, we confirm that municipalities with contest-free elections (the number of candidates is equal or less than assigned seats) have much lower voter turnout. Moreover, the increase in the number of candidates per voter also increases voter turnout, which may be due to the personal ties with candidates.

Sociológia 2020, Vol. 52 (No. 3: 222-244)

https://doi.org/10.31577/sociologia.2020.52.3.10
\end{abstract}

Key words: Voter turnout; turnout; quality of life; local politics; incumbent; competitiveness

\section{Introduction}

Voter turnout has been the interest of researchers for decades (Cancela - Geys 2016; Geys 2006; Stockemer 2017). Indeed, turnout is important to democracy because it is one of the most important indicators of democratic performance (Powell 1982). In general ${ }^{3}$, higher turnout is perceived as a positive for a democratic society (Wallace - Pichler 2009). Researchers have examined what impacts turnout (Blais 2006; Ivaldi et al. 2017). The socioeconomic variables have a strong potential to impact turnout. The socioeconomic variables are becoming increasingly important, as is the effort to gather the respondent's socioeconomic profile (Burden - Wichowsky 2014). At the same time, the research should not be limited to the national level but also extend to the

\footnotetext{
${ }^{1}$ The article was created within the grant project no. 20-02098S "Political competition and local democracy in comparative perspective" funded by the Czech Science Foundation (Grantová agentura České republiky).

2 Address: Mgr. Michael Haman - Mgr. Milan Školník, Department of Political Science, University of Hradec Králové. Rokitanského 62, 50003 Hradec Králové, Czech Republic. E-mail: milan.skolnik@uhk.cz, michael.haman@uhk.cz

3 However, there have been arguments that the quality of vote decreases with higher turnout and low turnout might be "a blessing in disguise" (Rosema 2007).
} 
municipal level (Frandsen 2002; van Houwelingen 2017). Municipalities are also subject of academic interest. Especially in terms of economy, financing, and self-management (Plaček et al. 2016; Ryšavý - Bernard 2013; Zdražil Pernica 2018). Indeed, a well-managed city can cause the satisfaction of its inhabitants (Kala 2011), and this may affect voter turnout. Our goal is to find out whether socioeconomic and political variables are important determinants of voter turnout in Czech municipalities.

Socioeconomic variables may influence voter turnout. However, the research puzzle is in what direction. On the one hand, socioeconomic variables can increase voter turnout, but on the other hand, decrease it. At the aggregated level, it may be also possible that socioeconomic variables would have a null effect on voter turnout. There is a vast discussion about the importance of quality of life on individual and social actions in the social sciences (Henderson et al. 2000; Lieske 1990; Yonk - Smith 2018). Also, political variables may impact voter turnout. For example, the closeness of elections is an important determinant of voter turnout (Cancela - Geys 2016; Geys 2006). However, the question remains whether this also holds in Czech municipalities. Therefore, we use an original dataset with 6,229 municipalities (obce) that consist of information about socioeconomic and political variables. We use statistical methods including ordinary least squares (OLS) regression to analyze data. We contribute to the discussion about the influence of socioeconomic indicators on voter turnout (Blais - Dobrzynska 1998; Brady et al. 1995; Fornos et al. 2004; Mattila 2003; Powell 1982), and more specifically about this influence in Czech municipalities.

In the Czech Republic, voter turnout is very topical research agenda as there have been numerous studies about voter turnout at the aggregated level (Kostelecký 2005, 2011; Kostelecký - Krivý 2015; Kouba 2015; Linek 2004), but also at the individual level (Linek 2004, 2011; Vlachová 2012). However, we extend these studies by exploring new variables and data, as explained later in the article, and we contribute to this research agenda with new insights about Czech municipalities. More generally, the research of the local politics is one of the major current topics in the Czech political science literature (Balík 2008a, 2008b, 2009; Bernard 2012; Čmejrek et al. 2009; Čmejrek et al. 2010; Čopík 2013, 2014; Čopík et al. 2019; Kopřiva et al. 2017; Kot’átková Stránská 2012; Ryšavý - Bernard 2013; Voda - Svačinová 2019; Voda et al. 2017).

This article examines only voter turnout at the aggregated level in Czech municipalities. The contextual factors are important for voter's decisionmaking in elections (Bernard - Kostelecký 2014). In the case of the Czech Republic, there have been plentiful studies confirming non-homogenous electoral behavior across the country especially based on the spatial support of 
political parties (Kabát - Pink 2006; Kostelecký 2001; Kostelecký et al. 2014; Kouba 2007; Maškarinec 2017; Pink et al. 2012).

However, in our analysis, we do not only include 6.229 municipalities. Moreover, we also use a more comprehensive index for 205 Czech municipalities with extended jurisdiction and Prague that not only gives information about traditional socioeconomic indicators but also about the extended concept of quality of life. Obce v datech (2019) constructed a unique index of quality life that offers complex information about Czech municipalities. However, data are only available for municipalities with extended jurisdiction. In the Czech case, municipalities with extended jurisdiction are an intermediary of delegated powers of self-government between regional authorities (kraje) and other municipal (obec) authorities, and their number including Prague is 206.

In practice, a municipality with extended jurisdiction is usually a large municipality (obec). We are aware of the limitations of these aggregated indices, and we use this index with caution. We use the index of quality life only in one model, and we test its relationship to voter turnout. The index of quality life is often presented in Czech newspapers and other media (Deník.cz 2018; Hospodářské Noviny IHNED 2018; Lidovky.cz 2018). Therefore, we assume that the index also deserves cautious testing at the scientific level in one of our models to see what predictive power the index might have and what new information the index may offer.

The article consists of three parts. The first part is theoretical, and we present theoretical assumptions and formulate our hypotheses. The second part is a methodology, and we introduce our variables, models, and methodological process. The third and final part is the interpretation of the findings.

\section{Theory}

\section{Political variables}

Electoral competitiveness is one of the most frequent variables that the researches use for analyzing voter turnout. Moreover, usually, this variable is significant in the explaining of voter turnout (Cancela - Geys 2016; Geys 2006). The more competitive the election is, the greater voter turnout is (Blais 2000; Blais - Dobrzynska 1998; Caldeira - Patterson 1982; Franklin - Hirczy 1998). Competitiveness mobilizes voters because voters consider that their votes have greater weight than an election with one dominant party. This argument is based on the theory of rational choice (Downs 1957) that supposes that rational voters vote when their votes can decide elections. In a close municipal election, one vote could determine its outcome more likely than in a national election with a dominant party. 
Moreover, politicians are also aware of the closeness of the race. Therefore, they mobilize their supporters and citizens when they feel they could win a race. Politicians invest more resources into close elections to try to win them, and this impacts overall mobilization (Aldrich 1993, 1995; Cox - Munger 1989; Kirchgässner - Schulz 2005; Rosenstone - Hansen 1993). It is clear that electoral closeness is an essential variable. However, we discuss in the methodological part whether closeness is a good measure of competitiveness in the Czech Republic, and we suggest better ways to operationalize competitiveness in municipal elections. Nevertheless, the first hypothesis is:

H1: The more competitive the electoral race, the higher the voter turnout.

The size of the municipality influences local politics. For example, the size of the municipality is an important determinant of the type of campaign. Oliver et al. (2012: 20) argue that electoral politics change significantly depending on town size. While personal connections dominate as a type of electoral politics in small towns (under 10,000 inhabitants), mass advertising and group appeals are common electoral strategy in large towns (over 100,000 inhabitants). The literature suggests that face-to-face canvassing boosts voter turnout (Gerber Green 2000; Nickerson et al. 2006; Niven 2004). In small municipalities, faceto-face canvassing is not so much needed as it is likely that the residents of municipality already know candidates personally. However, if needed, a candidate can more easily approach voters face-to-face than a candidate in a large city. Therefore, it would not be surprising if small municipalities would have a higher turnout as inhabitants are more likely to know candidates personally than people living in large municipalities.

Kostelecký (2005) finds that smaller municipalities have higher voter turnout than larger municipalities in metropolitan areas in the Czech Republic. As already mentioned, people living in smaller municipalities more likely to know local politicians and can contact them more easily, often in informal ways, in comparison to residents living in large municipalities. Voters can also have better knowledge in smaller municipalities about local politics as local politics is not as complex as national politics and might be for voters easily comprehensible. Moreover, following local politics is in voters' interest. The size of the municipality causes that any action performed by a mayor can affect them directly.

It is safe to assume that indeed the personal knowledge of running candidates is more likely in small municipalities than in large municipalities. However, the size of the municipality does not necessarily offer information about candidates. Smaller municipalities have a lower number of local representatives than larger municipalities. Therefore, one may assume that smaller municipalities would have a lower number of candidates as not as 
many local representatives can be elected as in larger municipalities. However, the question is what effect may have a different number of candidates in the same or similar sized municipalities. Especially in small municipalities, we expect that when a higher number of candidates run, there is a greater likelihood that a voter can know some of the candidates very closely as a neighbor, friend or even family member. Therefore, our second hypothesis is:

$\mathrm{H} 2$ : The higher the number of candidates per voter, the higher the voter turnout.

\section{Socioeconomic variables}

Socioeconomic variables are often part of studies examining voter turnout (Cancela - Geys 2016; Geys 2006; Stockemer 2017). However, there is mixed evidence about their effect on voter turnout. In comparative political science research, there are two theories that could help explain voter turnout. The first theory is modernization, and the second theory is disenchantment. Modernization is a historical process of systemic changes of socio-economic nature. Modernization has led to an increase in living standards, education, urbanization, but also to the emergence of democratization. The modernization theory (Inglehart 1997) links this with higher civic requirements for political participation (Norris 2002; Vráblíková 2009).

Favorable socioeconomic living conditions in industrialized democracies (in modernized societies) lead to higher turnout (Blais - Dobrzynska 1998; Brady et al. 1995; Fornos et al. 2004; Mattila 2003; Powell 1982). The citizens living in modernized areas are better informed, and because of their socio-economic profile, they have more time for public affairs than, for example, low-income citizens, for whom family financial security is a priority. Thus, one could argue that personal prosperity is a prerequisite for one's interest in politics. Education is also a prerequisite for participation.

However, development and good economic results do not always foster turnout. Radcliff (1992) finds that it is the opposite case in developing countries. Poor macroeconomic indicators raise turnout because citizens try to make their situation better through elections. Therefore, poor economic results can mobilize citizens rather than demobilize (Pacek - Radcliff 1995). The disenchantment (Pacek et al. 2009) theory partially opposes modernization theory and takes into account different development in Western and Eastern Europe. Therefore, disenchantment could be either depressing or mobilizing. Also, one could argue that citizens have more at stake in the poorer countries. They could mobilize to change their negative situations (Pacek et al. 2009).

However, both mentioned theories are very problematic to apply at the local level. In political science research, these theories are usually tested with countries as units of analysis. The reasoning is very simple; we can expect significantly different development trajectories across countries or even 
continents, but at the local level, we cannot expect high variations across municipalities within one country. This is especially in the case of the Czech Republic, a country that is highly homogenous and relatively small in size. However, these are not the only theories that could help explain voter turnout. Generally, the research about the relationship between voter turnout and socioeconomic variables can be divided into two groups.

Researchers in the first group, they argue that economic hardship causes mobilization effect Schlozman and Verba (1979). People are not happy with their living situation, blame political leaders, and they are prone to participate in protests, but also in elections. This could also be called the theory of "negative voting" (Lau 1982) as it assumes that people rather want to punish politicians in bad times than reward them in good times. However, researchers in the second group, argue in a similar vein as modernization theory. They expect that people living in economic distress more likely withdraw from political participation as they must care for themselves and their families, and they do not have enough time to follow politics as financial situation is a priority for them. Moreover, people living in poor areas usually are less educated than people living in wealthy areas. More educated citizens participate more in politics as they can understand political processes more easily through acquired knowledge (Powell 1982).

Therefore, even though the significance and direction of the relationship between the socioeconomic variable and voter turnout are not clear, we assume that people living in Czech municipalities with better conditions are more likely to participate in elections. This reasoning is twofold. First, in the Czech Republic, research at the individual level clearly shows that wealthier and more educated people are more likely to turn up on election day than people with a lower salary and less education (Vlachová 2012: 51-53). Also, Rosenstone (1982) argues that socioeconomic factors influencing voter turnout may also hold at the aggregated level, and not necessarily only at the individual level. Indeed, there is some evidence (Balík 2009: 169; Kostelecký 2005) that socioeconomic variables also hold at the municipal level in the Czech Republic. Therefore, the third hypothesis:

H3: The greater the quality of life in municipalities, the greater turnout.

\section{Methodology}

\section{Data}

We used data from several sources. The main source was the Czech Statistical Office (Český statistický úrad, ČSÚ) that provided open data for results of elections and several other variables about Czech municipalities that are described in more detail below. Also, we created the original dataset about 
Czech mayors. In the Czech Republic, there is no central database about the mayors of Czech municipalities. Therefore, we needed to create it using web pages of municipalities and other online sources. We identified a mayor of each municipality before the 2018 municipal elections. We used this dataset for our research. The third source was the Map of enforcement proceedings, Mapa exekucí, (Mapa exekucí 2019) that offers information about distraint in the Czech Republic as later in the article will be explained. Therefore, we created a dataset with 6,229 cases of Czech municipalities.

However, we also created the second dataset with 205 municipalities with extended jurisdiction and Prague. We included in this dataset the same variables as for all 6,229 municipalities in the first dataset, but also added variable from another source that was the project the Municipalities in data, Obce v datech, (Obce v datech 2019). The data of this project are available only at the level of municipalities with extended jurisdiction.

\section{Dependent variable}

Our dependent variable was voter turnout. We relied on data from the ČSÚ that provided data about electoral results, including voter turnout.

\section{Independent variables}

In our research, we include political and socioeconomic variables. From political variables, the key variable is competitiveness. However, electoral competitiveness can be measured in different ways. The most frequent measurement is the difference between the first and second party in elections. This simple difference in percentage points between the first and the second party in elections is called closeness (Cancela - Geys 2016; Geys 2006). Researches use this measurement especially in single-member district (SMD) elections under plurality voting. Under proportional representation in multimember districts (MMD), there is less consensus on how to measure competitiveness (Cox et al. 2019).

In Czech municipal elections, voters can vote for the whole electoral/party ${ }^{4}$ list or different candidates across candidate (electoral) lists. They vote in MMD under proportional representation. The number of seats in a district is based on the size of the municipality and limited by law. However, municipalities determine the exact number of seats within a lawful limit. Therefore, municipalities can have a different number of seats and have the same number of inhabitants. The particularity of Czech local politics is the great number of municipalities and their size. Almost $80 \%$ of Czech municipalities do not exceed 1,000 inhabitants. The small size of municipalities determines political competition as

4 Candidate lists can also present the association of independent candidates or candidates themselves. 
many municipalities have only one candidate list. Therefore, competitiveness in Czech municipalities must be examined with suitable measurements. In Czech municipalities, Ryšavý and Bernard (2013) measure competitiveness as the number of candidates on one seat.

Similarly, Bubeníček (2010) also distinguishes the models of local democracy in Czech municipalities and he considers municipalities as non-pluralist democracies when there are not more candidates in an election than assigned seats. When all parties run with a full number of candidates on their candidate lists in a municipality, then the number of candidates per seat equals the number of parties in elections. The number of candidates is considered as a measurement of political fragmentation (Geys 2006).

However, in Czech municipalities, the number of candidates per seat makes more sense as a measurement of competitiveness than closeness in small municipalities. In the case of one candidate list, the closeness would be $100 \%$. Nevertheless, in municipal practice, three candidate lists do not necessarily mean more competition than two lists. It can be that two of them are "friendly" against the opposition party and use the electoral system to their advantage. Still, two candidate lists generally mean more competition than only one list. Therefore, we use two dummy variables in our models. The first dummy is called Non-pluralism following Bubeníček's (2010) terminology. We coded Non-pluralism as 1 when the number of candidates per seat was equal or less than 1 , and we coded as 0 when the number of candidates was greater than 1 . When a municipal non-pluralism occurs, voters know with certainty that all candidates will be elected. Therefore, this election is contest-free. The second dummy is called Two+ candidate lists, and we coded it as one when there were at least two candidates lists in a municipality. Even though these two dummy variables are similar, they vary in the measurement. It is possible to have an election with seven candidate lists of individuals ${ }^{5}$ competing for seven seats. In this case, the variable Non-pluralism is 0 , but the variable Two+ candidate lists is 1 .

We also use closeness in models that include municipalities with extended jurisdiction as these municipalities are larger, and in the 2018 municipal elections, each municipality with extended jurisdiction presented more than one candidate list, but we know the limitation of this variable under proportional representation. Another variable is the number of candidates per voter. The higher values of this variable should indicate better personal knowledge of running candidates. We multiplied by 100 and logged this variable because of the high skewness caused by great variance in the size of municipalities.

5 In this context, we mean by individual candidate lists a situation when there is only one person on the candidate list. 
We use several socioeconomic variables that are available at the level of Czech municipalities and are commonly part of political science research. These socioeconomic variables offer information about the quality of life in municipalities. The quality of life is a part of third hypothesis. The first variable is unemployment at the end of September ${ }^{6} 2018$ provided by the Ministry of Labour and Social Affairs. As already mentioned, the indicator provided by Mapa exekuci offers information about the financial distress of inhabitants in municipalities. The variable financial distress is the percentage of population 15 years and older in a municipality that is in enforcement proceedings (exekuce). People are in the enforcement proceedings ${ }^{7}$ when they are not able to meet their financial obligations. Therefore, this variable offers more information about economic problems. While unemployment is problematic for society, the more people are in the enforcement proceedings than unemployed in the Czech Republic. Also, we include the percentage of the population with tertiary education as we assume that more educated electorate is generally better off. These data were from the 2011 census of the Czech Republic (Sčitání lidu, domů a bytů 2011 v Česku).

Moreover, in Czech municipalities with extended jurisdiction and Prague, we use more complex and innovative variable concerning the quality of life. The researchers use different measurements of development. They often use the gross domestic product (GDP). However, the GDP is not a comprehensive indicator. Even though it is hard to argue against the notion that economic development is not one of the main indicators of quality, it does not offer a full picture of the quality of life. Some argue that researches should try not to use only the GDP and use more complex indices (Costanza et al. 2014; Yonk Smith 2018). Therefore, the scholars often prefer the Human development index (HDI) that is used by the United Nations Development Program (UNDP) when the data are available. The HDI is not composed only of economic indicators, but also provides information about education and health. More specifically, the HDI has three dimensions that are long and healthy life, knowledge, and a decent standard of living. The following indicators are used for these three dimensions: life expectancy at birth, mean years of schooling, expected years of schooling, and the gross national income (GNI) per capita.

Of course, there is even more complex measurement of the development, such as the Multidimensional Poverty Index (MPI) (United Nations Development Programme 2013). However, it is very problematic to apply these indices to Czech municipalities. First, the ČSÚ does not calculate these indices. The

6 The latest data before the 2018 municipal elections.

7 These proceedings are also known as distraint or distress. 
ČSÚ offers many statistical data about municipalities, and it should be possible similar indices calculate. Nevertheless, the Czech Republic has a very high HDI (United Nations Development Programme 2018). The differences between municipalities are not significant in the basic indicators that are used by the UNDP in comparison to the less developed countries where there are often great differences between municipalities and regions. For example, the differences between municipalities with extended jurisdiction concerning life expectancy are only slight (Obce v datech 2019).

Obce v datech offers a unique index about quality of life, and we used the 2018 index. It combines traditional measurement of development with more complex indicators about the state of the municipality to provide more information. This approach is not new in the social sciences. Similarly, Yonk and Smith (2018) also developed the index of quality life that includes indicators of public safety, economic development, health, education, and infrastructure (Yonk - Smith 2018: 31). Therefore, we used the index of quality of life as our independent variable. The index of quality life is composed of three dimensions that are health and environment, work, education and standard of living, and community and services. All of these three dimensions are composed of subindices. Obce $v$ datech draws data from several sources such as the Czech Statistical Office, the National Register of Health Service Providers, the Ministry of Labour and Social Affairs, the Ministry of Education, Youth and Sport, and many others.

For the first dimension ${ }^{8}$, Obce $v$ datech calculates the number of practitioner's offices, pediatrician's offices, pharmacies, life expectancy, air pollution, protected natural areas in the municipalities in their dimension health, and environment. However, Obce v datech also takes into account a driving range of the municipality's town hall that set as a 30-minute to the offices or pharmacy related to the municipality's population. The second dimension that is work, education, and standard of living, includes unemployment; available job offers published on job portals and by Labour office, affordable housing, material insufficiency, financial distress, kindergarten, and elementary school capacity and quality of high schools. The third ${ }^{9}$ imension that is community and services compose of indices of supermarkets, ATMs, restaurants, cinemas, road network, railway transportation, traffic accidents, gambling, migration of the young people, and population increase. Similarly to the practitioner's and

\footnotetext{
${ }^{8}$ We highly recommend to a reader to visit the official webpage of Obce $v$ datech (Obce v datech 2019) where the index and its methodology is described in more detail. In this article, we offered a basic description of this index to save space.

9 In the third dimension, Obce $v$ datech also includes participation in regional and local elections. These elections are municipal elections in 2014 and regional elections in 2016. Therefore, we must note that previous elections are partially included in the index of quality of life. However, their overall weight is only $1.7 \%$. Thus, they have only a slight impact on the overall index, and it would not change the results of our research.
} 
pediatrician's offices, Obce v datech calculates the number of supermarkets and other establishments or services related to the municipality's population and takes into account the driving range.

From the mentioned above, it is clear that Obce $v$ datech created a complex index that can help to answer the question of what the impact the quality of life has on voter turnout. However, this variable is only in one model as several variables used in the index of quality life are used in models separately for all Czech municipalities. The same index of quality of life is almost impossible to calculate for 6,229 Czech municipalities. Therefore, it covers only 205 municipalities with extended jurisdiction and Prague.

\section{Control variables}

The first control variable is the number of registered voters (the electorate), and we logged this variable. Population and electorate size are frequently included in the research as a variable when the dependent variable is voter turnout (Geys 2006; Stockemer 2017). Again, the argument based on the theory of rational choice (Downs 1957) supposes that the voter turnout would be lower in municipalities with a greater population as voters are less likely to have a decisive vote. Another argument supposes that small units have a more homogenous population and closer relations between voters and representatives (Geys 2006; Stockemer 2017). The size of the municipality is considered to be a key factor for voter turnout in the Czech municipal elections. The smaller Czech municipalities have a higher voter turnout (Balík et al. 2015).

The second control variable is the percentage of the population 65 years old and older. These data were from the 2011 census of the Czech Republic (Sčitání lidu, domů a bytů 2011 v Česku).

The incumbent is the third control variable as the previous study carried out at the municipal level has hypothesized that if the incumbents do not run for election, it boosts voter turnout as voters certainly decide on a new mayor (Balík 2009: 169). When the incumbent decided to run, we code it as 1.

\section{Models}

We used the OLS regression as the dependent variable (voter turnout) is continuous in models. More specifically, it is voter turnout in the 2018 municipal elections in each municipality. We have a total of five models. Model 1 and Model 2 include all ${ }^{10}$ 6,229 Czech municipalities. In Model 3, we included only municipalities with a population of up to 2,000 inhabitants. We followed the

\footnotetext{
${ }^{10}$ As of 2018, ČSÚ states that there are 6,258 Czech municipalities including training areas (vojenské újezdy). However, of course, there are no elections in training areas. We do not include newly created municipalities after the 2011 census. Also, several municipal elections were invalided and had to be repeated, and we could not include these municipalities.
} 
research of Czech municipalities that traditionally ${ }^{11}$ has considered a rural municipality with a population of up to 2,000 (Čmejrek et al. 2010: 89-93). In Model 4 and Model 5, we included the variable the number of candidates per seat to function also as a measurement of political fragmentation. We did not use dummy variables as it did not make sense because all 206 municipalities have at least two candidate lists, and non-pluralism was not present in any of them. Also, we did not include the variable number of candidates per voter because of multicollinearity, but also because it is more unlikely to have a personal knowledge between candidates and voters in larger municipalities. Model 5 included the index of quality of life, and we excluded all variables that offered socioeconomic information, but we included the control variable the size of the electorate. We checked multicollinearity, and none of the models reached values that would signify a problem with multicollinearity. The highest variance inflation factor (VIF) was 2.87, and it was in Model 4. The mean of VIFs was 1.47 for Model 1, 1.40 for Model 2, 1.57 for Model 3, 1.79 for Model 4, and 1.51 for Model 5.

\section{Results}

Table 1 shows descriptive statistics for the first dataset with all municipalities and for the second dataset including only municipalities with extended jurisdiction and Prague separately. Table 2 presents the OLS regression models. Model 1 shows that non-pluralistic municipalities have lower voter turnout by $11 \%$. Model 2 confirms this finding also in municipalities with a population of up to 2,000 inhabitants. It is important to look at the relationship between candidates per seat and voter turnout. The number of candidates is heavily influenced by the size of the municipality as Ryšavý and Bernard (2013) correctly point out. In Figure 1, there are four plots of the relationship between voter turnout and four variables. The first plot $^{12}$ shows the variable of candidates per seat and it indicates that voter turnout increases with the number of candidates per seat up to two. Voter turnout decrease after two candidates per seat. This is caused by the fact that larger municipalities have lower voter turnout, but a higher number of candidates per seat. Therefore, Model 2 and 3 show results when we included only municipalities with a population of up to 2,000 inhabitants. The dummy variable of two and more candidate lists shows that in more competitive municipalities is higher voter turnout.

\footnotetext{
11 There are many definitions of rural municipalities. The other statistical definitions can consider 1,000 or 3,000 as a population limit for rural municipalities (Čmejrek et al. 2010: 89-93).

12 The plot uses a generalized additive model (GAM) with integrated smoothness estimation. This plot visually limits the $\mathrm{x}-$ axis to 13 , but the underlying data were not changed. The other plots use linear models.
} 
Table 1: Descriptive statistics

\begin{tabular}{|c|c|c|c|c|c|c|c|c|}
\hline Variables & Mean & St. Dev. & Min & Max & Mean & St. Dev. & Min & $\operatorname{Max}$ \\
\hline Turnout & 60.5 & 12.0 & 20.8 & 98.4 & 43.4 & 6.1 & 29.9 & 59.8 \\
\hline $\begin{array}{l}\text { Size of electorate } \\
\text { (logged) }\end{array}$ & 6.0 & 1.2 & 2.7 & 13.7 & 9.4 & 0.9 & 7.7 & 13.7 \\
\hline Incumbent & 0.9 & 0.3 & 0.0 & 1.0 & 0.9 & 0.2 & 0.0 & 1.0 \\
\hline $\begin{array}{l}\text { Candidates per voter } \\
\text { (logged) }\end{array}$ & 1.6 & 0.7 & -1.8 & 3.8 & 0.5 & 0.5 & -1.8 & 1.7 \\
\hline Tertiary education & 7.4 & 4.0 & 0.0 & 32.4 & 11.1 & 3.4 & 4.4 & 29.3 \\
\hline $65+$ electorate & 15.9 & 4.4 & 1.3 & 53.3 & 16.2 & 1.6 & 12.1 & 20.1 \\
\hline Closeness & & & & & 11.7 & 11.6 & 0.0 & 55.3 \\
\hline Unemployment & 2.6 & 1.7 & 0.0 & 15.6 & 2.9 & 1.4 & 0.7 & 8.9 \\
\hline Financial distress & 7.4 & 5.5 & 0.0 & 51.2 & 10.0 & 4.1 & 3.6 & 23.7 \\
\hline Non-pluralism & 0.1 & 0.3 & 0.0 & 1.0 & & & & \\
\hline Two+ candidate lists & 0.7 & 0.4 & 0.0 & 1.0 & & & & \\
\hline Candidates per seat & & & & & 8.8 & 2.7 & 3.0 & 24.3 \\
\hline Index of quality of life & & & & & 4.9 & 1.5 & 0.0 & 10.0 \\
\hline Observations & 6229 & & & & 206 & & & \\
\hline
\end{tabular}

Notes: 6,229 observations (dataset with all Czech municipalities); 206 observations (dataset with only municipalities with extended jurisdiction and Prague)

Source: Authors' calculation

Under Model 3, voter turnout is higher in a municipality with two and more candidate lists by $10 \%$ while holding all other variables constant. Also, Model 2 and Model 3 indicate that voter turnout increases with higher the number of candidates per voter. Therefore, municipalities where the personal knowledge of running candidates is more likely, they have higher voter turnout. In Figure 1 , the second plot visualizes this relationship. Therefore, we confirmed the first and second hypotheses. Model 1 to Model 4 show the same results concerning socioeconomic variables offering information about the quality of life. The better socioeconomic conditions, the higher voter turnout in municipalities. However, especially the variable financial distress is significant ${ }^{13}$. In Model 1, voter turnout decreases by $0.45 \%$ for every one percentage point of inhabitants in enforcement proceedings. The range between the municipality with the lowest and highest share the inhabitants in enforcement proceedings is $51 \%$. Therefore, Model 1 expects that the difference in voter turnout between these two municipalities would be almost $25 \%$, while holding all other variables constant.

13 In Figure 1, the third plot visualizes this relationship. However, we attached only the plot with 205 Czech municipalities with extended jurisdiction and Prague to clearly see significance of this variable. 
Table 2: The OLS regression models

\begin{tabular}{|c|c|c|c|c|c|}
\hline \multicolumn{6}{|l|}{ Dependent variable: } \\
\hline \multicolumn{6}{|c|}{ Voter turnout in the 2018 municipal elections } \\
\hline & \multicolumn{5}{|c|}{ Models: } \\
\hline & $(1)$ & $(2)$ & (3) & (4) & $(5)$ \\
\hline Non-pluralism & $\begin{array}{l}-11.247^{\text {*** }} \\
(0.305)\end{array}$ & $\begin{array}{l}-10.803^{\text {*** }} \\
(0.317)\end{array}$ & & & \\
\hline Two+ candidate lists & & & $\begin{array}{l}10.434^{* * *} \\
(0.283)\end{array}$ & & \\
\hline Candidates per voter & $\begin{array}{l}8.107^{* * * *} \\
(0.216)\end{array}$ & $\begin{array}{l}9.037^{* * *} \\
(0.237)\end{array}$ & $\begin{array}{l}7.219^{* * * *} \\
(0.256)\end{array}$ & & \\
\hline Candidates per seat & & & & $\begin{array}{l}0.526^{* * *} \\
(0.134)\end{array}$ & $\begin{array}{l}0.491^{* *} \\
(0.155)\end{array}$ \\
\hline Incumbent & $\begin{array}{l}0.320 \\
(0.298)\end{array}$ & $\begin{array}{l}0.286 \\
(0.315)\end{array}$ & $\begin{array}{l}0.021 \\
(0.310)\end{array}$ & $\begin{array}{l}1.192 \\
(1.077)\end{array}$ & $\begin{array}{l}1.274 \\
(1.266)\end{array}$ \\
\hline Closeness & & & & $\begin{array}{l}0.051^{*} \\
(0.021)\end{array}$ & $\begin{array}{l}0.034 \\
(0.025)\end{array}$ \\
\hline Financial distress & $\begin{array}{l}-0.450^{* * *} \\
(0.019)\end{array}$ & $\begin{array}{l}-0.432^{* * *} \\
(0.020)\end{array}$ & $\begin{array}{l}-0.397^{* * *} \\
(0.020)\end{array}$ & $\begin{array}{l}-0.534^{* * *} \\
(0.085)\end{array}$ & \\
\hline Unemployment & $\begin{array}{l}-0.190^{* * *} \\
(0.057)\end{array}$ & $\begin{array}{l}-0.197^{* *} \\
(0.060)\end{array}$ & $\begin{array}{l}-0.122^{*} \\
(0.059)\end{array}$ & $\begin{array}{l}-0.395 \\
(0.202)\end{array}$ & \\
\hline Tertiary education & $\begin{array}{l}0.237^{* * *} \\
(0.026)\end{array}$ & $\begin{array}{l}0.205^{* * *} \\
(0.029)\end{array}$ & $\begin{array}{l}0.223^{* * * *} \\
(0.029)\end{array}$ & $\begin{array}{l}0.553^{* * *} \\
(0.099)\end{array}$ & \\
\hline $65+$ electorate & $\begin{array}{l}0.081^{* * *} \\
(0.023)\end{array}$ & $\begin{array}{l}0.097^{* * * *} \\
(0.024)\end{array}$ & $\begin{array}{l}0.085^{* * * *} \\
(0.024)\end{array}$ & $\begin{array}{l}0.287 \\
(0.162)\end{array}$ & \\
\hline Quality of life & & & & & $\begin{array}{l}2.129^{* * *} \\
(0.182)\end{array}$ \\
\hline Size of electorate & $\begin{array}{l}-2.839^{* * *} \\
(0.121)\end{array}$ & $\begin{array}{l}-1.885^{* * *} \\
(0.171)\end{array}$ & $\begin{array}{l}-3.757^{* * *} \\
(0.191)\end{array}$ & $\begin{array}{l}-4.532^{* * *} \\
(0.444)\end{array}$ & $\begin{array}{l}-4.342^{* * *} \\
(0.447)\end{array}$ \\
\hline Constant & $\begin{array}{l}66.832^{* * *} \\
(1.094)\end{array}$ & $\begin{array}{l}59.893^{* * *} \\
(1.429)\end{array}$ & $\begin{array}{l}64.288^{* * *} \\
(1.442)\end{array}$ & $\begin{array}{l}75.113^{* * *} \\
(3.910)\end{array}$ & $\begin{array}{l}67.748^{* * *} \\
(3.736)\end{array}$ \\
\hline Observations & 6,229 & 5,532 & 5,532 & 206 & 206 \\
\hline $\mathrm{R}^{2}$ & 0.623 & 0.573 & 0.586 & 0.709 & 0.591 \\
\hline
\end{tabular}

Note: Standard errors in parentheses, ${ }^{*} \mathrm{p}<0.05 ;{ }^{* *} \mathrm{p}<0.01 ;{ }^{* * *} \mathrm{p}<0.001$

Source: Authors' calculation

Sociologia 52, 2020, No. 3 
The models show that the running incumbent does not have an effect on voter turnout ${ }^{14}$. These findings are interesting in the context of previous research in the Czech Republic. Indeed, the previous research conducted at the local level has hypothesized that if the incumbents do not run for election, it increases voter turnout as voters certainly decide on a new mayor (Balík 2009: 169). Thus, this hypothesis was not confirmed. However, Balík's (2008b) research was based on the observations of only two districts (okresy). Therefore, the difference between our and his results can be found in the complexity of studies as we did not limit ourselves only to two districts, but we analyzed with statistical methods dataset covering all municipalities in the Czech Republic.

Closeness in elections quite surprisingly has a positive relationship with voter turnout. However, the B coefficients are rather low in Models 4 and Model 5, and it does not reach even statistical significance in Model 5. Therefore, even though this measurement of competitiveness may be a useful and good predictor of voter turnout in SMD elections, one may argue that it is not a suitable measurement in Czech municipal conditions under proportional representation. As for the number of candidates per voter, this variable has a statistically significant positive relationship, but the B coefficient (0.526) is quite low. The difference between the mean and minimal value of this variable is 1.62. Therefore, the model predicts difference not even $1 \%$ in voter turnout between a municipality with the average and a minimal number of candidates per seat while holding all other variables constant. As mentioned, Model 1 to Model 4 show the importance of socioeconomic variables. Also, Model 5 shows that the index of quality of life and turnout have a significant positive association. Therefore, the third hypothesis is supported. It seems that inhabitants of municipalities with lower quality of life are discouraged from participating in the political process. They probably do not believe that elections can change their situation. The scale of the index of quality of life is from 0 to 10 (for example, Orlová is rated 0 and Říčany 10). It means that for every point in this index, the model predicts higher participation by $2.1 \%$. Therefore, the model expects the difference in voter turnout between the worst and best-rated municipality $21.6 \%$. In Figure 1, the third plot visualizes the relationship between voter turnout and this variable. Also, the fourth plot shows the relationship between voter turnout and financial distress in municipalities with extended jurisdiction and Prague.

\footnotetext{
${ }^{14}$ The Pearson correlation coefficient between these two variables is -0.057 .
} 
Figure 1: The relationship between voter turnout and four variables
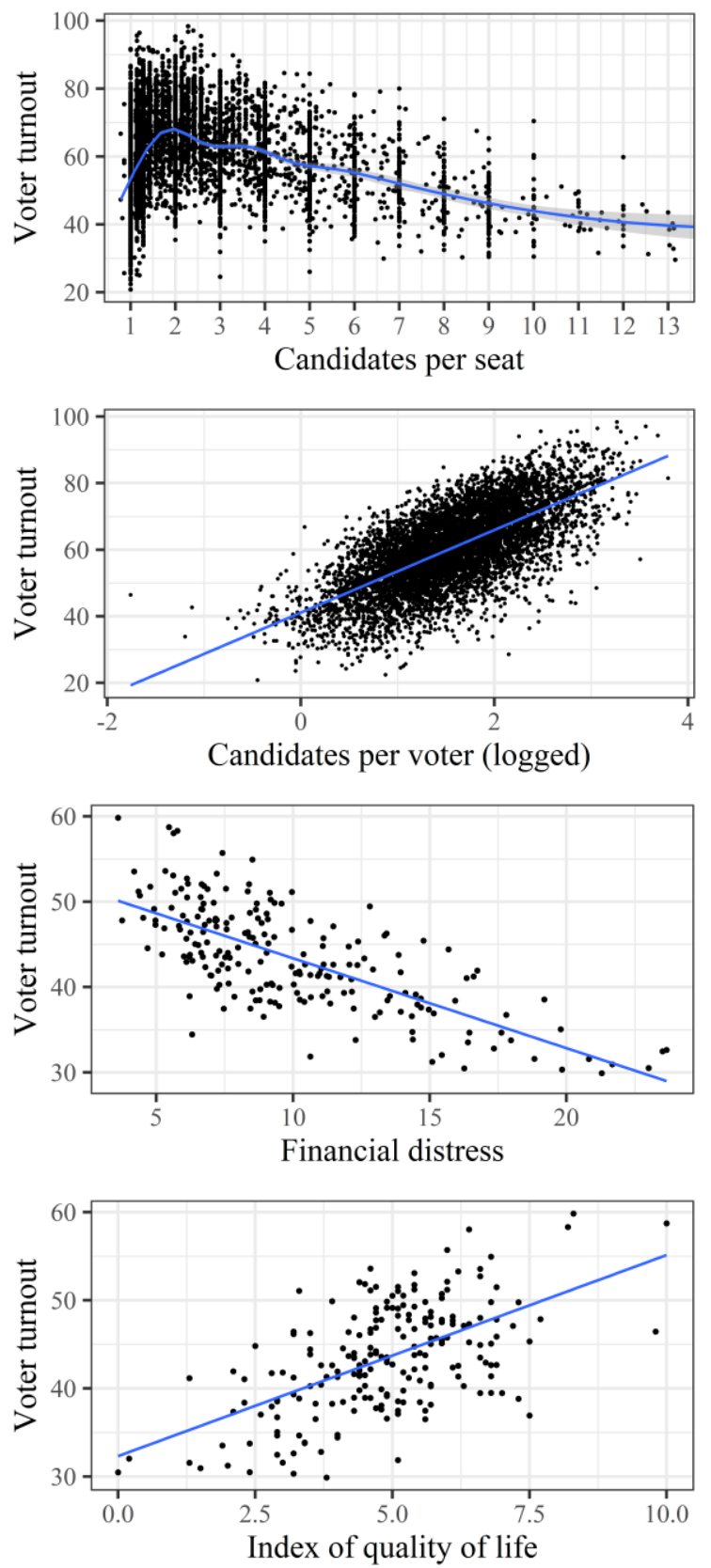

Source: Authors' calculation 


\section{Conclusion}

The aim of the article was to contribute to the research that examines the relationship between voter turnout and socioeconomic and political variables. We constructed the original dataset that consisted of 6,229 municipalities. We reached our conclusions by using the OLS regression models. We followed and extended previous research on voter turnout in the Czech Republic (Kostelecký 2005, 2011; Kostelecký - Krivý 2015; Linek 2004). However, we chose an innovative approach and included variables that have not yet been included in the research. Also, we created the second dataset that included only 205 Czech municipalities with extended jurisdiction and Prague. This dataset included the index of quality of life provided by the project of Obce $v$ datech that has not yet been explored in political research.

From political variables, we included in all models the variable about incumbents and their efforts to get reelected. We created this variable using web pages of municipalities and other online sources because of the absence of a central database about the mayors. We found that a running incumbent did not have an effect on voter turnout. This finding is in contrast to the Balík's assumption (Balík 2009: 169) that the absence of mayor's efforts to get reelected increases voter turnout as voters know that they surely decide about a new mayor because incumbent does not run. However, we confirmed the past research (Balík et al. 2015; Ryšavý - Bernard 2013) that indeed smaller municipalities have a higher voter turnout. We explored the possible measurement of competitiveness in Czech municipalities. We found that municipalities with a population of up to 2,000 inhabitants have higher voter turnout by $10 \%$ when there are at least two candidate lists while holding all other variables constant in one of our models. Also, when in the non-pluralistic municipalities, the number of candidates per seat does not exceed 1, municipalities have lower voter turnout by $11 \%$. Therefore, competitiveness has a significant positive association with voter turnout in small Czech municipalities.

On the other hand, in municipalities with extended jurisdiction and Prague, the closeness of elections does not increase voter turnout. Closeness is in a majority of studies important determinant of voter turnout (Cancela - Geys 2016; Geys 2006). However, this is not a case in Czech municipalities possibly because of MMD with proportional representation and not plurality voting with SMD. Also, we found out that there is a positive and significant association between voter turnout and the number of candidates per voter. The similarsized municipalities can have a different number of candidates and the number seats for elections. The high number of candidates per voter signifies it is more likely that a voter can know some of the candidates very closely as a neighbor, friend or even family member, and this variable can boost voter turnout. 
Socioeconomic variables have a great effect on voter turnout in Czech municipal elections. Better living conditions in municipalities increase voter turnout. Municipalities with a greater share of people in financial distress have a lower voter turnout. Unsurprisingly, the greater share of people with tertiary education also means higher voter turnout in a municipality. Also, we examined the relationship between the index of quality life and voter turnout in 205 municipalities and Prague and found out that this relationship is indeed positive and significant. We found out that our model expected the difference in turnout between the worst and best-rated municipality would be $21.6 \%$. Thus, poor living conditions rather discourage citizens from participating. In this article, one of our contributions is that we extended the current research on Czech municipalities with new variables concerning the quality of life.

Further research should examine the relationship between turnout and similarly complex index about quality of life in other countries. Again, we must stress that researchers should use more complex indicators than the GPD or even the HDI whenever possible especially in highly developed countries where the differences at the local level are not that great as in developing countries.

Michael Haman has a master's degree in political science from the University of Hradec Králové. He is a Ph.D. student in the Department of Political Science at the University of Hradec Králové. His current research focuses on elections, electoral behavior, electoral systems, and local politics.

ORCID iD https://orcid.org/0000-0001-5772-2045

Milan Školnik graduated from the Philosophical faculty of the University of Hradec Králové. He is currently an internal Ph.D. student of the Department of Political Science, FF UHK. He specializes in corruption, public administration, and political participation.

ORCID iD https://orcid.org/0000-0002-0672-219X

\section{REFERENCES}

ALDRICH, J. H., 1993: Rational Choice and Turnout. American Journal of Political Science 37(1) pp. 246-278.

ALDRICH, J. H., 1995: Why parties? The Origin and Transformation of Political Parties in America. Chicago: University of Chicago Press.

BALÍK, S. - GONGALA, P. - GREGOR, K., 2015: Dvacet let komunálních voleb v ČR. Brno: Centrum pro studium demokracie a kultury.

BALÍK, S., 2008a: Česká komunální politika v obcích s rozšířenou působností. Koalice, voličské vzorce a politické strany na místní úrovni v letech $1994-2006$. Brno: Centrum pro studium demokracie a kultury.

Sociologia 52, 2020, No. 3 
BALÍK, S., 2008b: Okresy na severu: Komunální politika v okresech Šumperk a Jeseník v letech 1989 - 2006. Brno: Centrum pro studium demokracie a kultury.

BALÍK, S., 2009: Komunální politika: obce, aktéři a cíle místní politiky. Praha: Grada Publishing.

BERNARD, J. - KOSTELECKÝ, T., 2014: Prostorový kontext volebního chování jak působí lokální a regionální prostředí na rozhodování voličů. Czech Sociological Review 50(3), pp. 3-28.

BERNARD, J., 2012: Individuální charakteristiky kandidátů ve volbách do zastupitelstev obcí a jejich vliv na volební výsledky. Sociologický C̆asopis/Czech Sociological Review 48(4), pp. 613-640.

BLAIS, A. - DOBRZYNSKA, A., 1998: Turnout in electoral democracies. European Journal of Political Research 33(2), pp. 239-261.

BLAIS, A., 2000: To Vote or not to Vote? The Merits and Limits of Rational Choice Theory. Pittsburgh: University of Pittsburgh Press.

BLAIS, A., 2006: What Affects Voter Turnout? Annual Review of Political Science 9(1), pp. 111-125.

BRADY, H. E. - VERBA, S. - SCHLOZMAN, K. L., 1995: Beyond Ses: A Resource Model of Political Participation. American Political Science Review 89(2), pp. 271294.

BUBENÍČEK, V., 2010: Lokální modely demokracie ve venkovských obcí ČR. In Čmejrek, J. - Bubeníček, V. - Čopík, J. (eds.): Demokracie v lokálním politickém prostoru. Praha: Grada Publishing, pp. 155-166.

BURDEN, B. C. - WICHOWSKY, A., 2014: Economic Discontent as a Mobilizer: Unemployment and Voter Turnout. The Journal of Politics 76(4) pp. 887-898.

CALDEIRA, G. A. - PATTERSON, S. C., 1982: Contextual Influences on participation in US state legislative elections. Legislative Studies Quarterly 7(3), pp. 359-381.

CANCELA, J. - GEYS, B., 2016: Explaining Voter Turnout: A Meta-Analysis of National and Subnational Elections. Electoral Studies 42, pp. 264-275.

ČMEJREK, J. - BUBENÍČEK, V. - ČOPÍK, J. 2010: Demokracie v lokálním politickém prostoru. Praha: Grada.

ČMEJREK, J. - ČOPÍK, J. - KOPŘIVA, R. - BUBENÍČEK, V. - KOCIÁNOVÁ, J. WAGNEROVÁ J., 2009: Participace občanů na veřejném životě venkovských obcí ČR. Praha: Kernberg Publishing.

ČOPÍK, J. - KOPŘIVA, R. - ČMEJREK, J., 2019: Mayors as a Variable in Typologies of Local Governments: A Case Study of the Czech Republic. Local Government Studies, pp. 1-19.

ČOPÍK, J., 2013: Proměny lokálních politických mechanismů v prostředí české územní samosprávy. Acta Politologica 5(2), pp. 125-142.

ČOPÍK, J., 2014: Proměny a kontinuita české komunální politiky: územní samospráva v nové době (1850 - 2010), Díl I - do roku 1945. Praha: Scriptorium.

COSTANZA, R. - KUBISZEWSKI, I. - GIOVANNINI, E. - LOVINS, H. MCGLADE, J. - PICKETT, K. E. - WILKINSON, R., 2014: Development: Time to Leave GDP Behind. Nature 505(74), pp. 283-285. 
COX, G. W. - FIVA, J. H. - SMITH, D. M., 2019: Measuring the Competitiveness of Elections. Political Analysis, pp. 1-18.

COX, G. W. - MUNGER, M. C., 1989: Closeness, Expenditures, and Turnout in the 1982 U.S. House Elections. The American Political Science Review 83(1), pp. 217 231.

DENÍK.CZ, 2018: „Nejlépe se žije v Říčanech, nejhưře na Ostravsku. Podívejte se na žebř́íček měst. Available from: https://www.denik.cz/z_domova/nejlepe-se-zije-vricanech-nejhure-na-ostravsku-podivejte-se-na-zebricek-mest-20180613.html.

DOWNS, A., 1957: An Economic Theory of Democracy. New York: Harper.

FORNOS, C. A. - POWER, T. J. - GARAND, J. C., 2004: Explaining Voter Turnout in Latin America, 1980 to 2000. Comparative Political Studies 37(8), pp. 909-940.

FRANDSEN, G. A., 2002: Size and Electoral Participation in Local Elections. Environment and Planning C: Government and Policy 20(6), pp. 853-869.

FRANKLIN, M. N. - HIRCZY, W. P., 1998: Separated Powers, Divided Government, and Turnout in U. S. Presidential Elections. American Journal of Political Science 42(1), pp. 316-326.

GERBER, A. S. - GREEN, D. P., 2000: The Effects of Canvassing, Telephone Calls, and Direct Mail on Voter Turnout: A Field Experiment. American Political Science Review 94(3), pp. 653-663.

GEYS, B., 2006: Explaining Voter Turnout: A Review of Aggregate-Level Research. Electoral Studies 25(4), pp. 637-663.

HENDERSON, H. - LICKERMAN, J. - FLYNN, P., 2000: Calvert-Henderson Quality of Life Indicators. Bethesda, MD: Calvert Group.

Hospodářské Noviny IHNED, 2018: Nejlépe se žije v Říčanech, předstihly i Prahu, nejhůře v Orlové na Karvinsku, ukázala analýza. Available from: https://byznys.ihned.cz/c1-66166790-nejlepe-se-zije-v-ricanech-predstihly-i-prahunejhure-v-orlove-na-karvinsku-ukazala-analyza

INGLEHART, R., 1997: Modernization and Postmodernization: Cultural, Economic, and Political Change in 43 Societies. Princeton, N.J.: Princeton University Press.

IVALDI, E. - BONATTI, G. - SOLIANI, R., 2017: An Indicator for the Measurement of Political Participation: The Case of Italy. Social Indicators Research 132(2), pp. 605-620.

KABÁT, M. - PINK, M., 2006: Parlamentní volby 2006 a volební geografie. In: Čaloud, D. (eds.): Volby do Poslanecké sněmovny v roce 2006. Brno: Centrum pro Studium Demokracie a Kultury.

KALA, T., 2011: Research on the Satisfaction of the Population with the Local Government in Municipalities in the Czech Republic. Proc. 2nd International Conference on Urban Sustainability, Cultural Sustainability, Green Development, Green Structures and Clean Cars (USCUDAR 11), pp. 70-75. Prague.

KIRCHGÄSSNER, G. - SCHULZ, T., 2005: Expected Closeness or Mobilisation: Why do Voters go to the Polls? Empirical Results for Switzerland, 1981 - 1999. No. 1387. Munich.

KOPŘIVA, R. - ČOPÍK, J. - ČMEJREK, J., 2017: Mechanismy rozhodování o investičních záměrech a rozpočtech obcí. Sociológia 49(5), pp. 482-506. 
KOSTELECKÝ, T. - KRIVÝ, V., 2015: Urbánno-rurálne rozdiely voličského správania v Česku a na Slovensku. Sociológia 47(4), pp. 390-413.

KOSTELECKÝ, T. - MIKEŠOVÁ, R. - POLÁKOVÁ, M. - ČERMÁK, D. BERNARD, J. - ŠIMON, M., 2014: Koho volí Vaši sousedé? prostorové vzorce volebního chování na území Česka od roku 1920 do roku 2006, jejich změny a možné prríčiny. Praha: Sociologické nakladatelství SLON.

KOSTELECKÝ, T., 2001: Vzestup nebo pád politického regionalismu? Změny na politické mapě v letech 1992 až 1998 - srovnání České a Slovenské republiky. Praha: Sociologický ústav AV ČR.

KOSTELECKÝ, T., 2005: Political Behavior in Metropolitan Areas in the Czech Republic between 1990 and 2002 - Patterns, Trends, and the Relation to Suburbanization and its Socio-Spatial Patterns. Praha: Sociologický ústav AV ČR.

KOSTELECKÝ, T., 2011: Politická participace: analýza účasti ve volbách v roce 2010 a jejích determinant. In: Čermák, D. - Vobecká, J. - et al., (eds.): Spolupráce, partnerství a participace v místní veřejné správě: význam, praxe, př́ílib. Praha: Sociologické nakladatelství SLON, pp. 60-83.

KOŤÁTKOVÁ STRÁNSKÁ, P., 2012: Analysis of Financing the Municipalities in the Czech Republic. International Journal of Mathematical Models and Methods in Applied Sciences 6(8), pp. 917-925.

KOUBA, K., 2007: Prostorová analýza českého stranického systému. Institucionalizace a prostorové režimy. Sociologický Časopis/Czech Sociological Review 43(5), pp. 1017-1037.

KOUBA, K., 2015: Proč ubývají voliči a neplatné hlasy ve druhých kolech českých senátních voleb. Sociologický Časopis/Czech Sociological Review 51(2), pp. 227260.

LAU, R. R., 1982: Negativity in Political Perception. Political Behavior 4(4), pp. 353377.

LIDOVKY.CZ, 2018: Nejlépe se prý žije v Říčanech, nejhůře zase v Orlové. Available from: https://www.lidovky.cz/domov/nejlepe-se-pry-zije-v-ricanech-nejhure-zasev-orlove.A180614_093048_ln_domov_sij

LIESKE, J., 1990: The Correlates of Life Quality in U.S. Metropolitan Areas. Publius: The Journal of Federalism 20(1), pp. 43-54.

LINEK, L., 2004: Volby do Evropského parlamentu 2004 - analýza volební účasti a stranické podpory v České republice. Praha: Sociologický ústav AV ČR.

LINEK, L., 2011: Proč se měnila úroveň účasti ve volbách do Poslanecké sněmovny v letech 1996 - 2010? Sociologický Časopis/Czech Sociological Review 47(1), pp. 9-32.

MAPA EXEKUCÍ, 2019: Available from: http://mapaexekuci.cz/mapa/index_en. html\#

MAŠKARINEC, P., 2017: A Spatial Analysis of Czech Parliamentary Elections, 2006 -2013. Europe - Asia Studies 69(3), pp. 426-457.

MATTILA, M., 2003: Why Bother? Determinants of Turnout in the European Elections. Electoral Studies 22(3), pp. 449-468. 
NICKERSON, D. W. - FRIEDRICHS, R. D. - KING, D. C., 2006: Partisan Mobilization Campaigns in the Field: Results from a Statewide Turnout Experiment in Michigan. Political Research Quarterly 59(1), pp. 85-97.

NIVEN, D. 2004: The Mobilization Solution? Face-to-Face Contact and Voter Turnout in a Municipal Election. The Journal of Politics 66(3), pp. 868-884.

NORRIS, P., 2002: Democratic Phoenix: Reinventing Political Activism. Cambridge: Cambridge University Press.

OBCE V DATECH, 2019: Available from: https://www.obcevdatech.cz/en/o-indexech

OLIVER, J. E. - CALLEN, Z. - HA SHANG, E., 2012: Local Elections and the Politics of Small-Scale Democracy. Princeton: Princeton University Press.

PACEK, A. - POP-ELECHES, G. - TUCKER, J. A., 2009: Disenchanted or Discerning: Voter turnout in post-communist countries. Journal of Politics 71(2), pp. 473491.

PACEK, A. - RADCLIFF, B., 1995: The Political Economy of Competitive Elections in the Developing World. American Journal of Political Science 39(3), pp. 745-759.

PINK, M. - EIBL, O. - HAVLÍK, V. - MADLEŇÁK, T. - SPÁČ, P. - VODA, P., 2012: Volební mapy České a Slovenské republiky po roce 1993: vzorce, trendy, proměny. Brno: CDK.

PLAČEK, M. - PŮČEK, M. - OCHRANA, F. - KŘÁPEK, M. - MATĚJOVÁ, L., 2016: Political Business Cycle in the Czech Republic: Case of Municipalities. Prague Economic Papers 25(3), pp. 304-320.

POWELL, B. G., 1982: Contemporary Democracies: Participation, Stability, and Violence. Cambridge: Harvard University Press.

RADCLIFF, B., 1992: The Welfare State, Turnout, and the Economy: A Comparative Analysis. American Political Science Review 86(2), pp. 444-454.

ROSEMA, M., 2007: Low Turnout: Threat to Democracy or Blessing in Disguise? Consequences of Citizens' Varying Tendencies to Vote. Electoral Studie 26(3), pp. 612-623.

ROSENSTONE, S. J. - HANSEN, J. M., 1993: Mobilization, Participation, and Democracy in America. New York: Macmillan.

ROSENSTONE, S. J., 1982: Economic Adversity and Voter Turnout. American Journal of Political Science 26(1), pp. 25-46.

RYŠAVÝ, D. - BERNARD, J., 2013: Size and Local Democracy: The Case of Czech Municipal Representatives. Local Government Studies 39(6), pp. 833-852.

SCHLOZMAN, K .K. - VERBA, S., 1979: Injury to Insult: Unemployment, Class, and Political Response. Cambridge, MA: Harvard University Press.

STOCKEMER, D., 2017: What Affects Voter Turnout? A Review Article/MetaAnalysis of Aggregate Research. Government and Opposition 52(4), pp. 698-722.

UNITED NATIONS DEVELOPMENT PROGRAMME, 2013: Calculating the Human Development Indices-Graphical Presentation. Available from: http://hdr.undp.org/sites/default/files/hdr_2013_en_technotes.pdf

UNITED NATIONS DEVELOPMENT PROGRAMME, 2018: Table 1. Human Development Index and its components. Available from: http://hdr.undp.org/sites/default/files/composite_tables/2018_Statistical_Annex_Ta ble_1.xlsx 
VAN HOUWELINGEN, P., 2017: Political Participation and Municipal Population Size: A Meta-Study. Local Government Studies 43(3), pp. 408-428.

VLACHOVÁ, K., 2012: Volební neúčast: kdo nešel k volbám? In Linek, L. (eds.): Voliči a volby. Praha: Sociologické nakladatelství (SLON), pp. 49-62.

VODA, P. - SVAČINOVÁ, P., 2019: To Be Central or Peripheral? What Matters for Political Representation in Amalgamated Municipalities? Urban Affairs Review.

VODA, P. - SVAČINOVÁ, P. - SMOLKOVÁ, A. - BALÍK, S., 2017: Local and More Local: Impact of Size and Organization Type of Settlement Units on Candidacy. Political Geography 59, pp. 24-35.

VRÁBLÍKOVÁ, K., 2009: Politická participace a její determinanty v postkomunistických zemích. Sociologický Časopis/Czech Sociological Review 45(5), pp. 867-897.

WALLACE, C. - PICHLER, F., 2009: More Participation, Happier Society? A Comparative Study of Civil Society and the Quality of Life. Social Indicators Research 93(2), pp. 255-274.

YONK, R. M. - SMITH, J. T., 2018: Politics and Quality of Life: The Role of WellBeing in Political Outcomes. Cham, Switzerland: Springer.

ZDRAŽIL, P. - PERNICA, B., 2018: Property Tax and Quality of Life in the Czech Municipalities: Does the Policy of Raising Local Coefficient Imply Potential or Risk for Development? Review of Economic Perspectives 18(2), pp. 123-136. 